\section{Antimicrobial Activity and B i ocompatibility of the Psidium cattleianum Extracts for Endodontic Purposes}

Loiane Massunari, Renata Zoccal Novais, Márcio Teixeira Oliveira, Diego Valentim, Eloi Dezan-Junior, Cristiane Duque
Department of Pediatric Dentistry and Public Health, Department of Endodontics, UNESP - Universidade Estadual Paulista, School of Dentistry, Araçatuba, SP, Brazil

Correspondence: Cristiane Duque, Rua José Bonifácio, 1193, 16015-050 Araçatuba, SP, Brasil. Tel: +55-18-3636-3315. e-mail: cduque@foa.unesp.br; cristianeduque@yahoo.com.br

\begin{abstract}
Psidium cattleianum (PC) has been displaying inhibitory effect against a variety of microorganisms, but this effect has not yet been tested against endodontic pathogens. The aim of this study was to evaluate the antimicrobial activity and biocompatibility of the aqueous (PCAE) and hydroethanolic (PCHE) extracts from Psidium cattleianum (PC) leaves. Minimum inhibitory concentration (MIC) and minimum lethal concentration (MLC) were determined using the microdilution broth method in order to analyze the antimicrobial effect against Enterococcus faecalis, Pseudomonas aeruginosa, Actinomyces israeliiand Candida albicans in planktonic conditions. Biofilm assays were conducted only with the extracts that were able to determine the MLC for microorganisms in planktonic conditions. Immediate and late tissue reactions against PC extracts were evaluated using edemogenic test and histological analysis of subcutaneous implants in Wistar rats. The results showed that the MIC and MLC values ranged between 0.25 and $4 \mathrm{mg} / \mathrm{mL}$. The MLC obtained for PCHE inhibited 100\% growth of all the tested strains, except for C. albicans. PCAE had the same effect for E. faecalis and P. aeruginosa. Both PC extracts were able to eliminate $E$. faecalis biofilms and only the PCHE eliminated $P$. aeruginosa biofilms. The positive controls inhibited the growth of all tested strains in MIC and MLC essays, but no $\mathrm{CHX}$ tested concentrations were able to eliminate $A$. israelii biofilm. PCAE caused a discrete increase in the edema over time, while PCHE caused a higher initial edema, which decreased progressively. Both PCAE and PCHE extracts were biocompatible, but PCHE showed better results with slight levels of inflammation at 28 days. In conclusion, PCHE was biocompatible and presented better antimicrobial effect against important pathogens associated with persistent endodontic infections
\end{abstract}

Key Words: dental pulp diseases, phytotherapeutic drugs, antimicrobial activity.

\section{Introduction}

The microbiota remaining after conventional endodontic treatment has been related to the maintenance or development of periapical diseases. The persistence of some microorganisms, like Enterococcus faecalis and Candida albicans in cases of endodontic treatment failures and Actinomyces israelii and Pseudomonas aeruginosa in refractory periapical lesions, associated with the complex anatomy of the root canal system require irrigants and dressings with a large spectrum of antimicrobial action for better disinfection (1-3). The most commonly used antimicrobial agents in endodontics are calcium hydroxide (CH) and chlorhexidine (CHX) $(4,5)$. Although most endodontic pathogens are effectively eliminated by $\mathrm{CH}$, E. faecalis and $C$. albicans can be resistant, depending on the $\mathrm{CH}$ vehicles (6). $\mathrm{CHX}$ has a reasonably wide range of activity against aerobic and anaerobic bacteria, as well as Candida species. Several studies have reported a better antimicrobial activity for $\mathrm{CHX}$ when used as an endodontic dressing, compared with $\mathrm{CH}$ and the association of $\mathrm{CHX}$ and $\mathrm{CH}$ (7-9). Although $\mathrm{CHX}$ is also a potent antimicrobial irrigant, its capacity of tissue dissolution is reduced and when in contact with a common endodontic irrigant, sodium hypochlorite, it results in a "potentially toxic precipitate" (10).

Herbal medicines are emerging as potential antioxidant and antimicrobial agents for the treatment of human diseases $(11,12)$ including those in oral cavity $(13,14)$. Species of Psidium have been largely studied due to its antimicrobial (11,13-15), anti-inflammatory (15), antioxidant and antiproliferative (13) properties. Psidium cattleianum (PC), commonly known as araçá or strawberry guava, belongs to the Myrtaceae family and is native from tropical America, although it may be cultivated in other countries because it tolerates a large diversity of climates (12). PC extracts have displayed inhibitory activity against oral microorganism (13). However, the antimicrobial effects of extracts from PC leaves have not yet been tested against pathogens related in endodontic infections. Thus, the aim of this study was to evaluate the biocompatibility and antimicrobial activity of the aqueous (PCAE) and hydroethanolic (PCHE) extracts 
obtained from PC leaves against persistent endodontic pathogens.

\section{Materials and Methods}

\section{Plants Extracts}

The leaves were collected in the Araçatuba School of Dentistry, UNESP, Araçatuba, SP, Brazil. The specimen, number HLF2006/7, was deposited at the Pharmacology and Research Herbarium, Phytotherapy Lab, São José do Rio Preto, SP, Brazil. The leaves were washed and dried at $37{ }^{\circ} \mathrm{C}$ for one week, when they become brittle and ground to a fine powder. Aqueous extract was obtained by decoction in deionized water $(20 \mathrm{~g} / 250$ $\mathrm{mL}$ ) for $5 \mathrm{~min}$ at $100{ }^{\circ} \mathrm{C}$ and at $55^{\circ} \mathrm{C}$ for an additional $1 \mathrm{~h}$. Hydroethanolic extract was obtained mixing $20 \mathrm{~g}$ of powdered leaves with $250 \mathrm{~mL}$ of $80 \%$ ethanol and shaking vigorously five times a day for 12 days (16). Both solutions were then filter sterilized with $0.22 \mu \mathrm{m}$ mixed cellulose ester membranes (EMD Millipore, Billerica, MA, USA). The hydroethanolic extract was concentrated under reduced pressures by a rotary evaporator (MA120/ TH; Marconi Marconi Equipamentos para Laboratórios Ltda, Piracicaba, SP, Brazil) linked to a vacuum pump (TE-058; Tecnal Equipamentos Científicos; Piracicaba, $\mathrm{SP}$, Brazil). The aqueous extract was incubated at $37{ }^{\circ} \mathrm{C}$ for $72 \mathrm{~h}$. Both dried extracts were stored in dark bottles at $-20{ }^{\circ} \mathrm{C}$ until use.

\section{Antimicrobial Properties of the Plant Extracts \\ Microbial Conditions}

The following microbial strains used in the present study were kindly provided by the Oswaldo Cruz Foundation (FIOCRUZ, Rio de Janeiro, RJ, Brazil): E. faecalis (ATCC 51299), Actinomyces israelii (ATCC 12102), P. aeruginosa (ATCC 15442) and C. albicans (ATCC 26790). The purity of the strains was confirmed by the Gram method. Microbial suspensions were prepared from overnight grown culture in Brain Heart Infusion broth (Ref.M210/ Lot.35340, Himedia, Mumbai, Maharashtra, India) for bacteria strains or Sabouraud Dextrose broth (Ref. 238230/ Lot. 2082199, Difco, Bordeaux, France) for C. albicans and incubated at $37{ }^{\circ} \mathrm{C}$ for $24 \mathrm{~h}$ in a $5 \% \mathrm{CO}_{2}$ (HF212-UV Ultra Safe Incubator; Progen Scientific Ltd, London, UK). All microorganisms were incubated in these atmospheric conditions to simulate low oxygen concentration inside root canals. Growth curve assays were performed for each microorganism in order to determine the optical density at the mid-log phase [approximately $0.5\left(5-10 \times 10^{8}\right.$ $\mathrm{CFU} / \mathrm{mL})$ for bacteria and $0.3\left(5-10 \times 10^{6} \mathrm{CFU} / \mathrm{mL}\right)$ for $C$. albicans at $550 \mathrm{~nm}$ ] to be used in the next experiments. The absorbance was measured using a microplate reader (Eon Microplate Spectrophotometer; BioTek Instruments,
Winooski, VT, USA) to assess the cell growth.

Determination of Minimum Inhibitory Concentration (MIC) and Minimum Lethal Concentration (MLC)

MIC and MLC were determined by microdilution broth method, in 96-well microtiter plates, following the criteria previously described by Clinical and Laboratory Standard Institute M7-A9 and M27-A3. The final concentration of bacterial suspension in the wells was $5-9 \times 10^{5} \mathrm{CFU} / \mathrm{mL}$ and $2.5-5 \times 10^{3} \mathrm{CFU} / \mathrm{mL}$ for C. albicans. Initially, the plant extracts were serially diluted in water and then the microbial suspensions (correctly adjusted for the concentrations), were inoculated in each well. The plates were incubated at $37^{\circ} \mathrm{C}$ for $24 \mathrm{~h}$ in a $5 \% \mathrm{CO}_{2}$ atmosphere. Afterwards, 15 $\mu \mathrm{L}$ of $0.01 \%$ Resazurin (R7017; Sigma-Aldrich, St. Louis, $\mathrm{MI}$, USA) was applied in each well and incubated for $4 \mathrm{~h}$ to promote oxidation-reduction and determine the cell viability by visually detected color change. Posteriorly, the wells corresponding to MIC (the least blue well) and at least three previous wells were homogenized, six times diluted and plated on Mueller-Hinton agar or Sabouraud Dextrose agar to determine the MLC. The plates were incubated at $37{ }^{\circ} \mathrm{C}$ for $24 \mathrm{~h}$ in a $5 \% \mathrm{CO}_{2}$ atmosphere. The colonies were counted and the number of viable bacteria was determined in CFU/mL. MLC was considered when the extracts/fractions killed over $50 \%$ to $100 \%$ of the tested microbial culture. Chlorhexidine digluconate (CHX) and Amphotericin $\mathrm{B}(\mathrm{AB})$ were used as positive controls. The negative controls were cultures without antimicrobial agents in their media. Assays were repeated three times for each microorganism, in three independent experiments.

\section{Biofilm Formation in Polystyrene Microplates}

Biofilm assays were conducted with the extracts that showed 100\% growth inhibition on the MLC tests. These assays were conducting according to Budzynska et al. (17), with some modifications. Twenty microliters of each microorganism suspension (approximately 5-9 $\times 10^{6}$ $\mathrm{CFU} / \mathrm{mL}$ ) were inoculated in sterile U-shaped bottom 96 well polystyrene microplates containing $180 \mu \mathrm{L} \mathrm{BHI}$ for bacteria or Sabouraud Dextrose broth for Candida, both supplemented with $0.5 \%$ glucose. The plates were incubated at $37{ }^{\circ} \mathrm{C}$ in a $5 \% \mathrm{CO}_{2}$ atmosphere. After $48 \mathrm{~h}$, the culture medium was removed and the wells were washed with sterile saline for subsequent addition of $200 \mu \mathrm{L}$ of plant extract solution in each well. The concentrations used for these assays were 5 and 10 times higher than the MLC concentration. The microplates were incubated again in the same conditions for $24 \mathrm{~h}$. All cultures in the wells were diluted six times and plated in Brain Heart Infusion agar or Sabouraud Dextrose agar and incubated for $24 \mathrm{~h}$. After this, the colony forming units (CFU)/mL was determined. CHX (at 
$5 \times$ or $10 \times$ MLC concentrations) and $A B($ at $5 \times$ or $10 \times M L C$ concentrations) were used as positive controls and biofilm in water without antimicrobial agents, as negative control. Assays were repeated three times for each microorganism, in three independent experiments.

\section{Biologic Tissue Responses to PCAE and PCHE \\ Immediate Tissue Reaction (Edemogenic Test)}

The animal experiment was approved by Animal Experimentation Ethics Committee of Araçatuba School of Dentistry (Process \#2008-000166). Eighteen 4-6 monthold Wistar male rats weighting 250-280g were divided in 6 groups of 3 animals according to the experimental period ( 3 and $6 \mathrm{~h}$ ) and treatment with hydroethanolic (PCHE) or aqueous (PCAE) extract, both with a $4.0 \mathrm{mg} / \mathrm{mL}$ concentration or saline (S) as control. Anesthetized animals received an intravenous injection of 2\% Evan's blue (0.1 $\mathrm{mL} / 100 \mathrm{~g}$ of body weight) (Evan's Blue; Difco Lab). After 30 $\min , 0.1 \mathrm{~mL}$ of the extracts or saline solution were injected at the dorsum region, near the tail and using the median line as a reference (16). After 3 and $6 \mathrm{~h}$ the animals were euthanized by anesthetic overdose and a fragment of the tissue with a $23 \mathrm{~mm}$ diameter containing a blue halo in the center was removed. The tissue was fixed in $4 \mathrm{~mL}$ of formamide for $72 \mathrm{~h}$ at $45{ }^{\circ} \mathrm{C}$ and filtered for posterior analysis in a spectrophotometer at $630 \mathrm{~nm}$.

\section{Late Tissue Reaction (Histological} Analysis)

Thirty 4-6 month-old Wistar male albino rats weighting $250-280 \mathrm{~g}$ were divided in groups of 5 for each experimental group (PCAE, PCHE and S) and period of time ( 7 and 28 days). Sixty polyethylene tubes with $1.0 \mathrm{~mm}$ inner diameter, $1.6 \mathrm{~mm}$ external diameter and $10 \mathrm{~mm}$ length with a paper cone, were prepared and filled with the extracts (at $40 \mathrm{mg} / \mathrm{mL}$ ) and saline and subcutaneously implanted according to Machado et al. (16). After 7 and 28 days of implantation the animals were killed by anesthetic overdose and tubes/surrounding tissue removed and fixed in 10\% formalin. Histological analysis was performed with a light microscope and original magnification of $40 x$ after hematoxylineosin staining. The quantitative analysis of inflammation was performed according to the number of inflammatory cells present and classified in the following scores $(16,18)$ : 0 : absent (absence of inflammatory cells), 1: low ( $<25$ inflammatory cells), 2 : moderate (25-125 inflammatory cells) and 3: severe $(>125$ inflammatory cells). For the thickness of fibrous capsule, the scores were: 0 : thin (thickness $<150 \mu \mathrm{m}$ ) and 1: thick (thickness $>150 \mu \mathrm{m}$ ).

\section{Statistical Analysis}

Data from planktonic growth in $\mathrm{MIC}$ and $\mathrm{MLC}$ conditions were converted to logarithm scale $\left(\log _{10}(\mathrm{CFU}+1)\right.$ and the percentage $(\%)$ of microbial reduction was compared to normal growth (control group). Box-whisker plots were performed to represent the distribution of non-parametric data obtained in the biofilm assays. Mann-Whitney tests were applied to compare experimental groups and the ones with positive control for microbiological assays. Results of edemogenic test were analyzed by two-way ANOVA complemented by Tukey test $(p<0.05)$. Data from histological study were analyzed by Mann-Whitney and Wilcoxon tests $(p<0.05)$.

\section{Results}

The MIC and MLC values in the present study ranged between $0.25 \mathrm{mg} / \mathrm{mL}$ and $4 \mathrm{mg} / \mathrm{mL}$ (Table 1). The results showed strong antibacterial activity of the Psidium cattleianum aqueous extract (PCAE) and Psidium cattleianum hydroethanolic extract (PCHE) against $E$. faecalis and $A$. israelii, and weak activity for $P$. aeruginosa in

Table 1. Minimum inhibitory concentration (MIC) and minimal lethal concentration (MLC) of Psidium cattleianum extracts

\begin{tabular}{|c|c|c|c|c|}
\hline Antimicrobial tested & Microorganism & $\begin{array}{c}\text { MIC } \\
(\mathrm{mg} / \mathrm{mL})\end{array}$ & $\begin{array}{c}\text { MLC } \\
50 \%-99.8 \% \\
(\mathrm{mg} / \mathrm{mL})\end{array}$ & $\begin{array}{c}\text { MLC } \\
99.9-100 \% \\
(\mathrm{mg} / \mathrm{mL})\end{array}$ \\
\hline \multirow{4}{*}{$\begin{array}{l}\text { Psidium cattleianum } \\
\text { aqueous extract } \\
\text { (PCAE) }\end{array}$} & E. faecalis & 0.5 & - & 0.5 \\
\hline & P. aeruginosa & 4 & - & 4 \\
\hline & C. albicans & $>4$ & $>4$ & $>4$ \\
\hline & A. israelii & 0.25 & $>4$ & $>4$ \\
\hline \multirow{4}{*}{$\begin{array}{l}\text { Psidium cattleianum } \\
\text { hidroethanolic extract } \\
\text { (PCHE) }\end{array}$} & E. faecalis & 0.5 & - & 0.5 \\
\hline & $P$. aeruginosa & 4 & - & 4 \\
\hline & C. albicans & $>4$ & $>4$ & $>4$ \\
\hline & A. israelii & 0.25 & - & 0.25 \\
\hline \multirow{3}{*}{$\begin{array}{l}\text { Chlorhexidine } \\
\text { digluconate } \\
\text { (CHX) }\end{array}$} & E. faecalis & 0.006 & - & 0.010 \\
\hline & P. aeruginosa & 0.04 & - & 0.08 \\
\hline & A .israelii & 0.001 & - & 0.001 \\
\hline Amphotericin B (AB) & C. albicans & 0.0002 & - & 0.0005 \\
\hline
\end{tabular}


planktonic conditions. Both extracts were unable to inhibit C. albicans growth by the microdilution broth method. The percentages of microbial reduction in MIC and MLC for Psidium cattleianum extracts are in Figure $1 \mathrm{~A}$ and $\mathrm{B}$, respectively. The values of MIC inhibited completely the growth of $E$. faecalis and $P$. aeruginosa for PCAE and $P$. aeruginosa and $A$. israelii for PCHE. P. aeruginosa was the most sensitive microorganism and presented $100 \%$ growth reduction in presence of MIC obtained for both extracts. C. albicans was the most resistant strain for both tested substances and no extract had effect on its growth. MLC obtained for PCHE inhibited 100\% growth of all the tested strains, except for C. albicans. The MLC for PCAE had the same effect for $E$. faecalis and $P$. aeruginosa. The positive controls (Chlorhexidine and Amphotericin B) inhibited the growth of all tested strains. Figure 2 shows box-whisker plots of the activity of the plant extracts against biofilms. PCHE ( $5 \times$ and $10 \times$ MLC), CHX and PCAE $(10 \times$ MLC) were able to completely eliminate the $E$. faecalis biofilm. The same was observed for PCHE (10x) and CHX (5x and 10x MLC) for $P$. aeruginosa. PCHE $(10 \times \mathrm{MLC})$ reduced the growth of A. israelii after $24 \mathrm{~h}$ of exposition. Both $\mathrm{CHX}(5 \mathrm{x}$ and $10 \mathrm{x}$ $\mathrm{MLC}$ ) tested were not able to eliminate $A$. israelii biofilm.

Figure 3 shows the results of edemogenic test. Saline and PCAE caused a discrete increase of edema over time while PCHE caused a higher initial edema that decreased gradually. Statistically significant differences were observed for edema between saline and PCHE $(p<0.05)$.
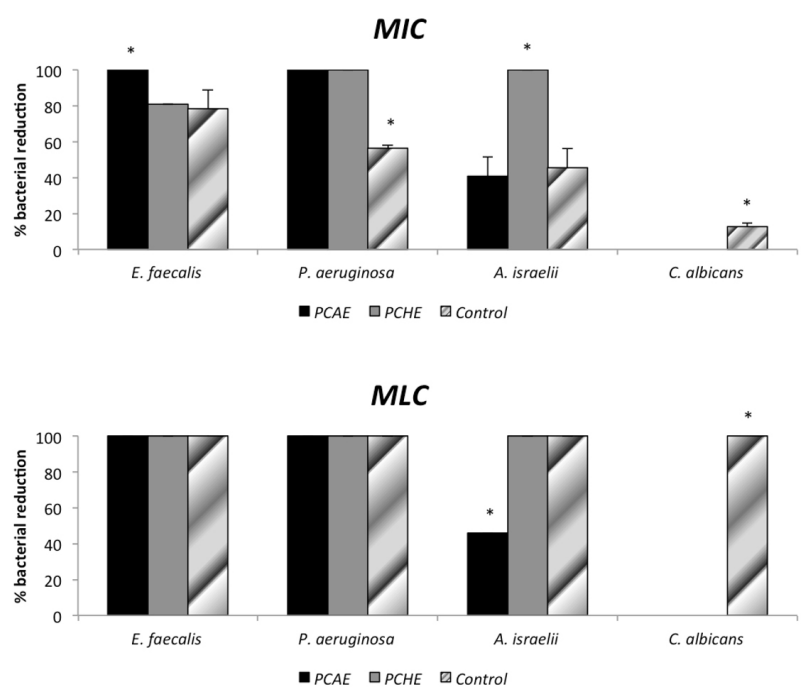

Figure 1. A: Percentage (\%) of microbial reduction compared to normal growth under minimum inhibitory concentration (MIC) of Psidium cattleianum extracts. B: Percentage (\%) of microbial reduction compared to normal growth under minimum lethal concentration (MLC) of Psidium cattleianum extracts. Data were expressed in mean of $\log (\mathrm{CFU}+1)$. Control for bacteria - CHX, Control for Candida albicans - AB. * - Statistical difference among the groups according to Mann-Whitney tests).
The medium scores of inflammatory cell counting after histological analysis are in Table 2. The saline group at 7 days presented the highest number of inflammatory cells and it was statistically different from other groups $(p<0.05)$. The results from PCHE at 7 days presented the second worst result, differing statistically from PCHE at 28 days and saline at 7 days groups $(p<0.05)$. PCHE at 28 days and saline 28 days presented the lowest numbers of inflammatory cells, but these values were not statistically significant different from PCAE ( $p>0.05)$. The thickness of fibrous capsule was statistically different between saline and the other groups, at 7 days. The qualitative evaluation of tissue response to both extracts (PCAE and PCHE) at 7 days showed a thick fibrous capsule with connective tissue in repair. There were numerous new fibroblasts and disorganized collagen fibers oriented parallel to the

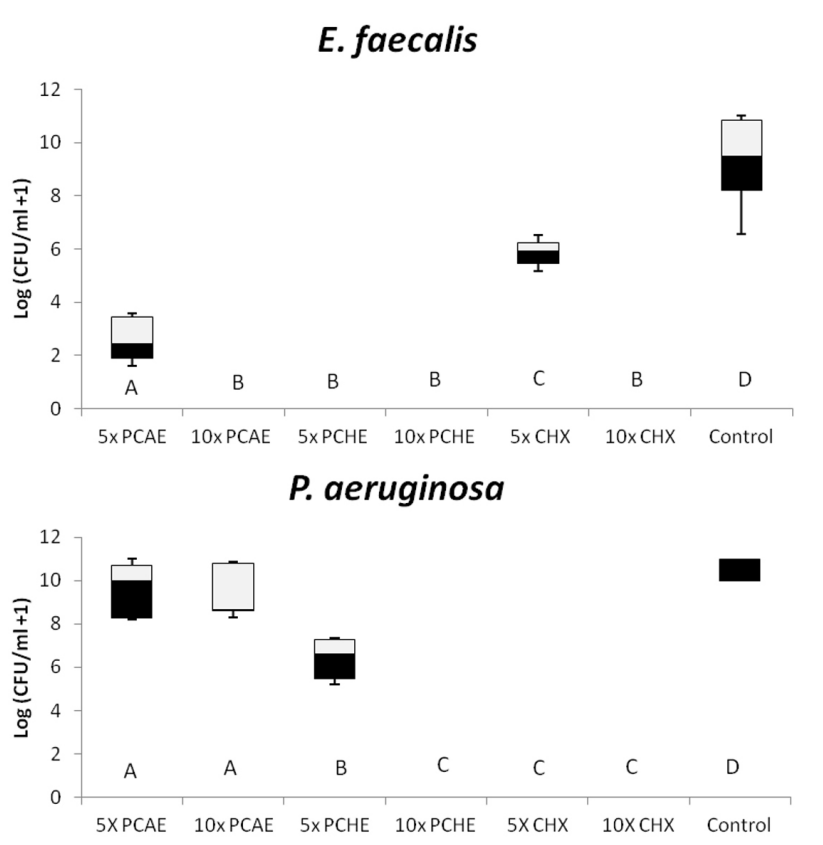

\section{A. israelii}

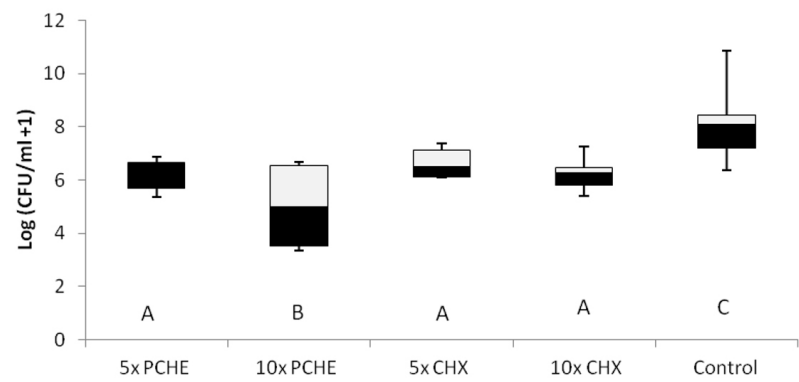

Figure 2. Box-whisker plots of the activity of the Psidium cattleianum extracts against biofilm of pathogenic microorganisms. Different capital letters show statistical difference among the groups and control $\left(\mathrm{H}_{2} \mathrm{O}\right)$, according to Mann-Whitney tests. Bars indicate minimum and maximum values. Black and white boxes indicate lower and upper quartiles, respectively. Line in the middle of boxes is median. 
implant. A layer of macrophages can be observed near the implant, and some cells were dispersed in the repair tissue. There are lymphocytes and mononucleated cells, characterizing a chronic inflammation with the presence of angiogenesis (Figs. 4A and 4C). The saline group at 7 days presented more aggressive inflammatory response. The area of tissue reaction was higher and the fibrous capsule was thicker with macrophages, lymphocytes, mononucleated cells and new fibroblasts. Collagen fibers were distributed in a complex position (Fig. 4E). The PCAE and saline groups at 28 days presented a great reduction of inflammatory reaction and a higher tissue organization. The fibrous capsule was thinner with organized collagen fibers parallel to the implant. The number of inflammatory cells was reduced. There were few vessels with small diameter in the connective tissue (Figs. 4B and 4F). The hydroethanolic group (PCHE) at 28 days presented a more homogenous repair than the other groups. The fibrous capsule was thin and condensed and the collagen fibers were thicker and organized. The fibroblasts showed an elongated and thin nucleus. The macrophages around the implant presented a slight diameter indicating attenuation on the phagocytic activity. Occasional plasma cells may be observed between ¿ the implant and the macrophages, suggesting a humoral response to PCHE (Fig. 4D).

\section{Discussion}

The complexity of root canals, the limitations of the chemomechanical preparation and the vulnerability of each species involved in the infection are well recognized factors related to the failure of an endodontic treatment (8). In alternative to solve this problem, several authors have been studying medicinal plants to improve the endodontic treatment $(19,21,22)$. In the present study, the objective was

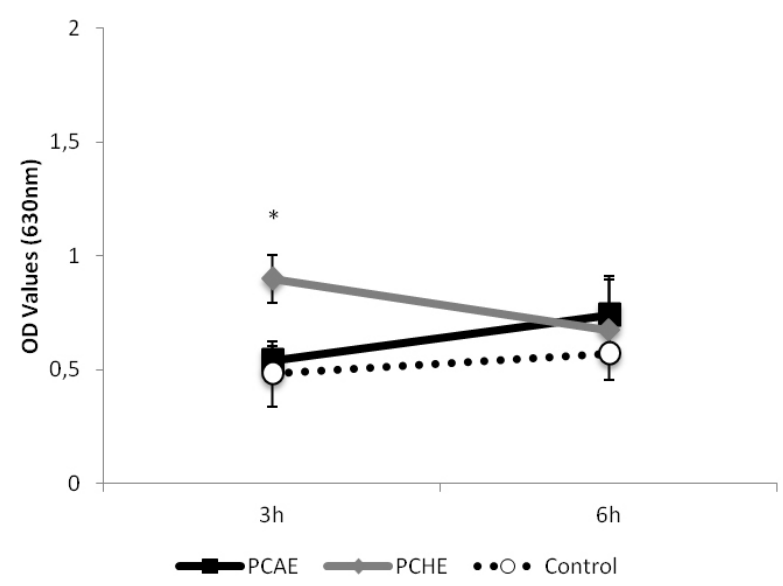

Figure 3. Means (standard deviations) values of edema on both periods of time for the PCAE, PCHE and control groups. *Statistical difference between PCHE and the other groups, according to ANOVA/Tukey tests. to analyze the antimicrobial activity of Psidium cattleianum extracts against microorganisms involved in the persistent endodontic infection, apart from analyzing their immediate and late biologic responses.

The antimicrobial properties of PC have been recently studied (11,13-15), but the direct comparison of the obtained results with the literature is difficult, since different methodologies and microorganisms were used in these investigations, only a parallel analysis was done. Similar to this study results, de Souza et al. (9) did not observe an effect against $C$. albicans in any of the 18 tested extracts, including the PC extract (11). PCAE showed antibacterial effect at high concentration in a reduced exposure time (5 $\mathrm{min}$ ) or at a low concentration in 60 min against the Streptococcus mutans biofilm (13). After treatment with PCAE, in an in situ biofilm assay, total anaerobic microorganism, total streptococci and S. mutans counts decreased when compared with water or antiseptic treatments (14). In the present study, the PCAE also presented antibacterial effect against the $E$. faecalis and $P$. aeruginosa biofilms and eliminated the E. faecalis biofilm at higher concentrations (10xMLC). In order to reduce the time for calcium hydroxide activity as an endodontic dressing, PCHE was used as a vehicle for calcium hydroxide in a biofilm assay. The tested formulation eliminated $E$. faecalis in $24 \mathrm{~h}$ (19). This study results also showed $E$. faecalis elimination when exposed to PCHE (5x and $10 \times M L C)$, suggesting that only the presence of the PC extract produced bactericidal effect.

The large range between the MIC and MLC values were observed in the results for PCAE extract - MIC $(0.25$ $\mathrm{mg} / \mathrm{mL}$ ) and $\mathrm{MLC}$ ( $>4 \mathrm{mg} / \mathrm{mL}$ ) against $A$. israelii. The same was also reported in studies using antibiotics and propolis against the same bacterium $(20,21)$. This suggested that the

Table 2. Medians (minimum-maximum) of scores for inflammatory cell infiltrate and thickness of fibrous capsule after 7 and 28 days of extract exposure

\begin{tabular}{llllll}
\hline \multirow{2}{*}{ Extract } & \multicolumn{2}{c}{$\begin{array}{c}\text { Inflammatory } \\
\text { cell infiltrate }\end{array}$} & & \multicolumn{2}{c}{$\begin{array}{c}\text { Fibrous } \\
\text { capsule }\end{array}$} \\
\cline { 2 - 3 } \cline { 5 - 6 } \cline { 5 - 6 } & 7 days & 28 days & & 7 days & 28 days \\
\hline PCAE & $2(1-2)$ & $2(1-2)$ & & $0(0-1)$ & $0(0-1)$ \\
PCHE & $2(1-2)$ & $1(0-2) \#$ & & $0(0-1)$ & $0(0-1)$ \\
Saline & $3(2-3)^{*}$ & $2(0-2)$ & & $1(0-1)^{*}$ & $0(0-1)$ \\
\hline
\end{tabular}

Inflammatory cell infiltrate: 0: absent (absence of inflammatory cells), 1: low (number of inflammatory cells <25), 2: moderate (25-125 inflammatory cells) and 3: severe ( $>125$ inflammatory cells). Thickness of fibrous capsule: 0 : thin (thickness $<150 \mu \mathrm{m}$ ), 1: thick (thickness $>150 \mu \mathrm{m})$. *In the columns, statistical difference between this group and the other ones, according to Mann-Whitney tests. \#In the rows, statistical difference between the groups, considering the periods of the experiments, according to Wilcoxon tests. 
slow rate of $A$. israelii elimination is due to the genotypic tolerance of the species (20).

$P$. aeruginosa was resistant to PC hexane, ethyl acetate and methanol fruit extracts by disc diffusion (15). In the present study, although others solvents and other tree parts were employed to obtain the PC extracts may observed the effect of PC extracts for both solvents against $P$. aeruginosa. Different results can be observed in other studies with plant material. This can occur due to the different methods of extraction employed and the different solvents used for

\section{Day 7}
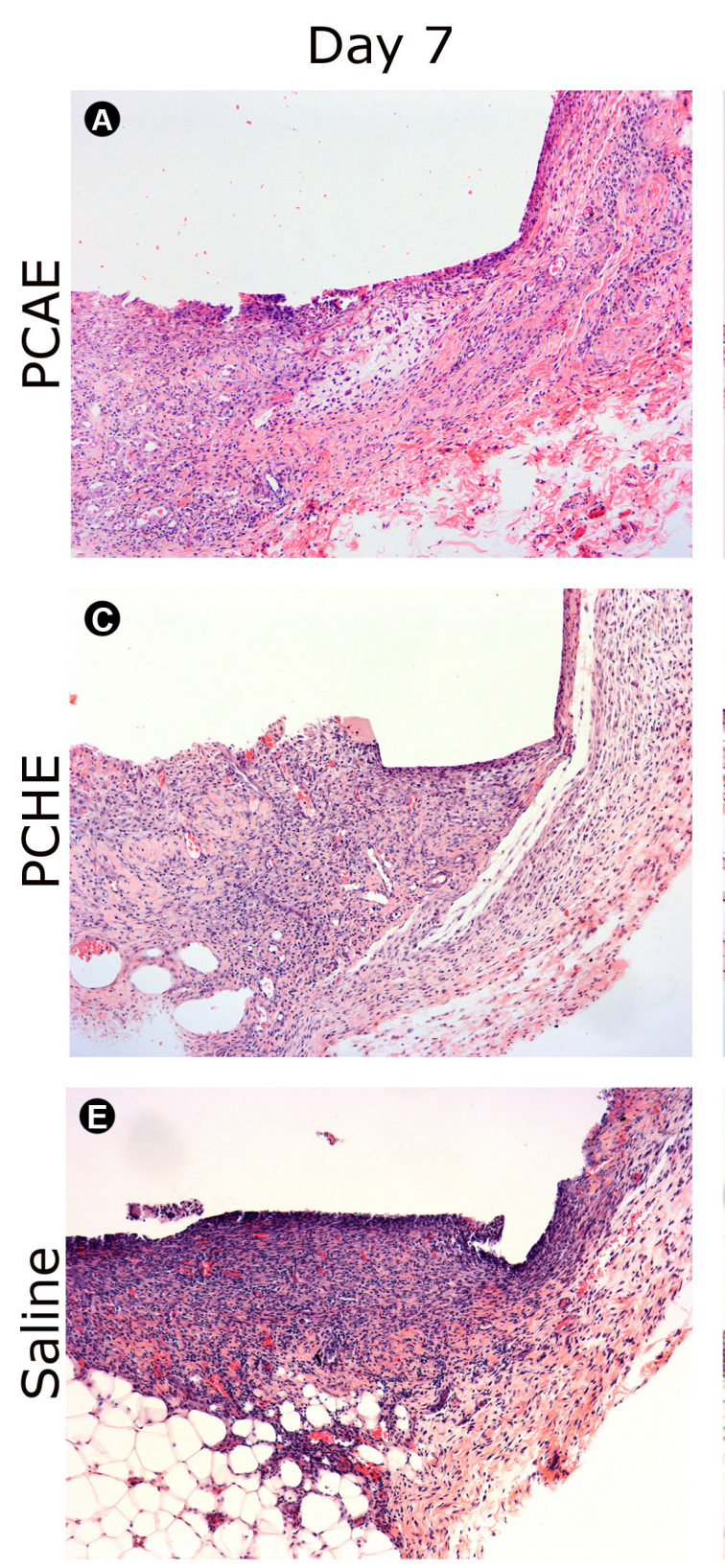

obtaining the crude extracts (23). Furthermore, the presence and concentration of the compounds may be different in each part of the tree (24).

The presence of the phenolic compounds - three flavonoids (kaempferol, quercetin and cyaniding) and tannin (ellagic acid) - have been related as the factor responsible for the $\mathrm{PC}$ antibacterial activity (13). Flavonoids are secondary metabolites naturally synthesized by plants, capable of penetrating into bacterial cells due to their lipophilic characteristic (25). Quercetin-5.3-dimethylether
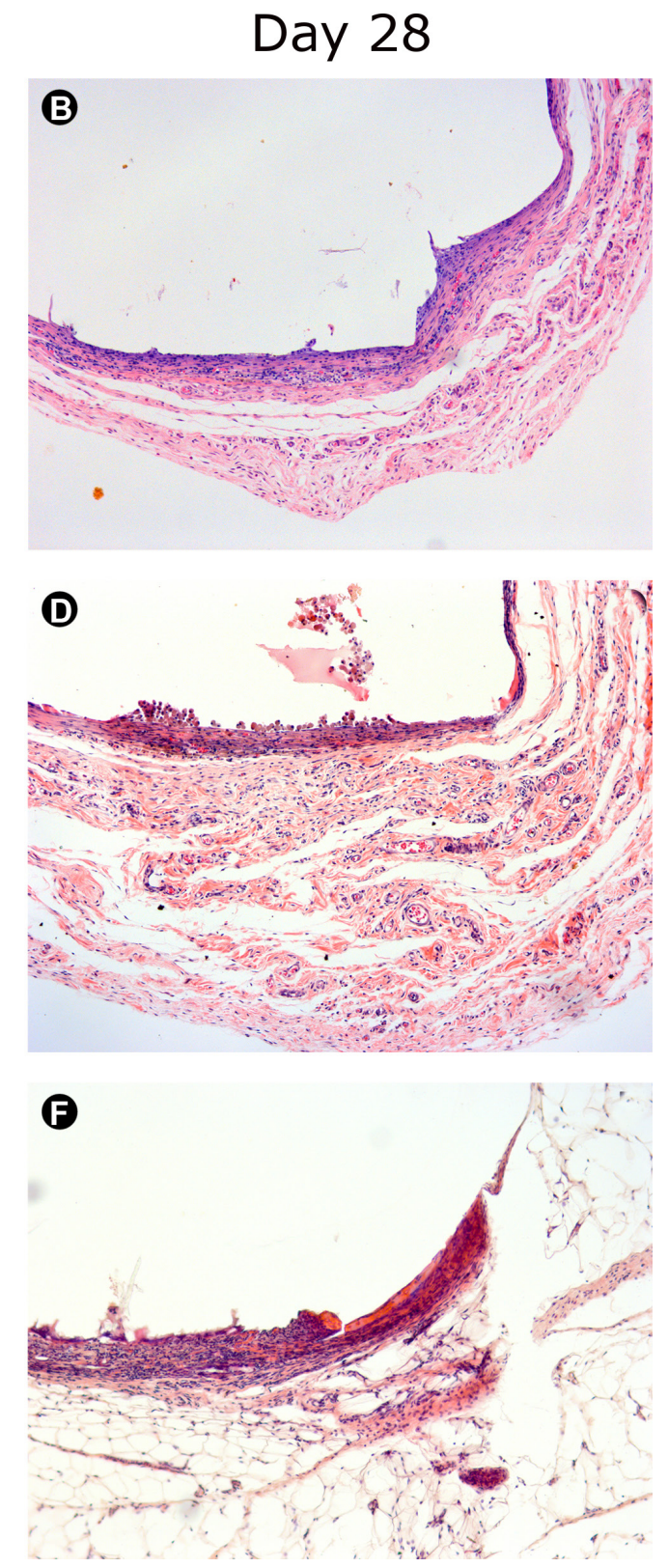

Figure 4. Representative images of histological findings in the area of tubes opening. Psidium cattleianum aqueous extract (PCAE) group: A: Day 7, moderate inflammatory cell infiltrate and thick fibrous capsule. B: Day 28, thin fibrous capsule and moderate inflammatory cell infiltrate. Psidium cattleianum hydroethanolic extract (PCHE) group: C: Day 7, thick fibrous capsule and moderate inflammatory cell infiltrate with the presence of lymphocytes and macrophages. D: Day 28, fibrous capsule around the tube was thinner with few chronic inflammatory cells. Saline group (control): E: Day 7, thick fibrous capsule and highest inflammatory cell infiltrate. F: Day 28, reduction of inflammatory cells and fibrous capsule near the tube. HE: Original magnification: 100x. 
from Combretum erythrophyllum displayed MICs values of 0.05 and $0.1 \mathrm{mg} / \mathrm{mL}$ for E. faecalis and P. aeruginosa, respectively (25). Tannins can be toxic to filamentous fungi, yeasts and bacteria due to their ability for inactivating microbial adhesins, enzymes and cell envelopes that transport proteins (26).

The present study demonstrated that the extracts are safe for use in biological tissues causing benefits to biologic response during repair. During the studied period, the wound healing was in an advanced stage presenting reduced levels of inflammation for PCAE and PCHE groups. These results were different from another study that followed the same methodology using Myracrodruon urundeuva aqueous and ethanolic extracts (16). The Myracrodruon urundeuva ethanolic extract demonstrated persistency of inflammation until the 28th day (16).

The edemogenic test showed a higher edema in the PCHE group at $3 \mathrm{~h}$, which probably occurred due to the ethanol. However, this edema reduced progressively. The morphological analysis showed repair progress over time proving that the implants did not interfere with natural repair progression. Both extracts induced better tissue responses than control group (saline) suggesting a beneficial effect of these extracts for inflammation control. This was observed at 7 days when there were moderate inflammatory responses mainly due to the surgical trauma to tissues. Besides, the inflammatory tissue reactions caused by PCAE and PCHE extracts were lower than those caused by saline (control). At 28 days there was a regression of inflammatory process in all groups, but PCHE showed better results with slight levels of inflammation.

This present study has some limitations. First of all, the complete neutralization of antimicrobial agents was not confirmed before plating. Two common methods are used for inhibition of residual biocides: dilution and chemical neutralization. In this study was used the dilution of the antimicrobial agents, 6 times before plating. The choice was to not use chemical neutralization of biocides because of the toxicity displayed by several types of neutralizers. The use of neutralizers could not distinguish between neutralization of the biocide versus recovery of organisms injured by sub-lethal exposure to the biocide (27). In the present study, was used a population of organisms without exposure to antimicrobial agents as a growth control. However, studies have appointed for the importance of the complete neutralization of biocides, like chlorhexidine, because the accuracy of a biocidal assay and low levels of residuals would lead to exaggerated results of microbicidal activity (27). Another limitation of this study is absence of dentin as a substrate for bacterial growth. This is the first study that found antimicrobial activity for the Psidium cattleianum extracts against endodontic pathogens and new studies are required to confirm this property simulating the canal root environment.

In conclusion, PCHE was biocompatible and presented good antimicrobial effect against important pathogens associated with persistent endodontic infections.

\section{Resumo}

Psidium cattleianum (PC) tem apresentado atividade inibitória frente diversos microrganismos, entretanto esse efeito ainda não foi testado contra microrganismos de interesse endodôntico. 0 objetivo desse estudo foi avaliar a atividade antimicrobiana e a biocompatibilidade dos extratos aquoso (EAPC) e hidroetanólico (EHPC) das folhas de Psidium cattleianum. As concentrações inibitória mínima (CIM) e letal mínima (CLM) foram determinadas pelo método de microdiluição em caldo, com o objetivo de analisar o efeito antimicrobiano frente Enterococcus faecalis, Pseudomonas aeruginosa, Actinomyces israelii e Candida albicans em condições planctônicas. Os ensaios de biofilme foram realizados somente com os extratos em que se determinou a CLM frente os microrganismos em condições planctônicas. Respostas teciduais imediata e tardia frente aos extratos de Psidium cattleianum foram avaliadas por teste edemogênico e análise histológica de implantes subcutâneos em ratos Wistar. Os resultados mostraram que CIM e CLM variaram entre 0,25 e $4 \mathrm{mg} / \mathrm{mL}$. As CLMs determinadas pelo EHPC inibiram 100\% do crescimento de todas as cepas testadas, exceto Candida albicans. EAPC apresentou o mesmo efeito para $E$. faecalis e $P$. aeruginosa. Ambos os extratos de PC conseguiram eliminar o biofilme de $E$. faecalis, e somente o EHPC eliminou o biofilme de $P$. aeruginosa. Os controles positivos inibiram o crescimento de todos os microrganismos testados nos ensaios de CIM e CLM, mas nenhuma das concentrações de clorexidina testadas foi capaz de eliminar o biofilme de $A$. israelii. 0 EAPC provocou um discreto aumento de edema com o tempo, enquanto EHPC provocou um edema inicial severo, que diminuiu progressivamente. Ambos os extratos EAPC e EHPC foram biocompativeis, entretanto, EHPC apresentou melhores resultados com baixos niveis de inflamação em 28 dias. Pode-se concluir que EHPC foi biocompativel e apresentou melhor efeito antimicrobiano frente importantes patógenos associados a infecções endodônticas persistentes.

\section{Acknowledgements}

The microbial strains were provided by Oswaldo Cruz Foundation (FIOCRUZ). This study was funded by CAPES (Coordenação de Aperfeiçoamento de Pessoal de Nivel Superior) from Brazil.

\section{References}

1. Sakamoto M, Siqueira JF Jr, Rôças IN, Benno Y. Molecular analysis of the root canal microbiota associated with endodontic treatment failures. Oral Microbiol Immunol 2008;23:275-281.

2. Siqueira JF Jr, Rôças IN. Clinical implications and microbiology of bacterial persistence after treatment procedures. Journal of Endodontics 2008;34:1291-1301.e3

3. Zhang S, Wang Q0, Zhang CF, Soo I. Identification of dominant pathogens in periapical lesions associated with persistent apical periodontitis. Chin J Dent Res 2010;13:115-121.

4. Mohammadi Z, Dummer PM. Properties and applications of calcium hydroxide in endodontics and dental traumatology. Int Endod J 2011;44:697-730.

5. Vaghela DJ, Kandaswamy D, Venkateshbabu N, Jamini N, Ganesh A. Disinfection of dentinal tubules with two different formulations of calcium hydroxide as compared to $2 \%$ chlorhexidine: As intracanal medicaments against Enterococcus faecalis and Candida albicans: An in vitro study. J Cons Dent 2011;14:182-186.

6. Turk BT, Sen BH, Ozturk T. In vitro antimicrobial activity of calcium hydroxide mixed with different vehicles against Enterococcus faecalis and Candida albicans. Oral Surg Oral Med Oral Pathol Oral Radiol Endod 2009;108:297-301. 
7. Gomes BP, Souza SF, Ferraz CC, Teixeira FB, Zaia AA, Valdrighi L, et al.. Effectiveness of 2\% chlorhexidine gel and calcium hydroxide against Enterococcus faecalis in bovine root dentine in vitro. Int Endod J 2003;36:267-275.

8. Gomes BP, Vianna ME, Sena NT, Zaia AA, Ferraz CC, de Souza Filho FJ. In vitro evaluation of the antimicrobial activity of calcium hydroxide combined with chlorhexidine gel used as intracanal medicament. Oral Surg Oral Med Oral Pathol Oral Radiol Endod 2006;102:544-550.

9. de Souza-Filho FJ, Soares A de J, Vianna ME, Zaia AA, Ferraz CC, Gomes BP. Antimicrobial effect and $\mathrm{pH}$ of chlorhexidine gel and calcium hydroxide alone and associated with other materials. Braz Dent J 2008;19:28-33.

10. Cintra LT, Watanabe S, Samuel RO, da Silva Facundo AC, de Azevedo Queiroz IO, Dezan-Júnior $\mathrm{E}$, et al.. The use of $\mathrm{NaOCl}$ in combination with CHX produces cytotoxic product. Clin Oral Invest 2014;18:935-940.

11. de Souza GC, Haas AP, von Poser GL, Schapoval EE, Elisabetsky E. Ethnopharmacological studies of antimicrobial remedies in the south of Brazil. J Ethnopharmacol 2004;90:135-143.

12. Biegelmeyer $R$, Andrade JM, Aboy AL, Apel MA, Dresch RR, Marin R, et al.. Comparative analysis of the chemical composition and antioxidant activity of red (Psidium cattleianum) and yellow (Psidium cattleianum var. lucidum) strawberry guava fruit. J Food Sci 2011;76:C991-996.

13. Brighenti FL, Luppens SB, Delbem AC, Deng DM, Hoogenkamp MA, Gaetti-Jardim E Jr, et al.. Effect of Psidium cattleianum leaf extract on Streptococcus mutans viability, protein expression and acid production. Caries Res 2008;42:148-154.

14. Brighenti FL, Gaetti-Jardim E Jr, Danelon M, Evangelista GV, Delbem AC. Effect of Psidium cattleianum leaf extract on enamel demineralisation and dental biofilm composition in situ. Arch Oral Biol 2012;57:10341040.

15. McCook-Russell KP, Nair MG, Facey PC, Bowen-Forbes CS. Nutritional and nutraceutical comparison of Jamaican Psidium cattleianum (strawberry guava) and Psidium guajava (common guava) fruits. Food Chem 2012;15;134:1069-1073.

16. Machado AC, Dezan Junior E, Gomes-Filho JE, Cintra LT, Ruviére DB, Zoccal R, et al.. Evaluation of tissue reaction to aroeira (Myracrodruon urundeuva) extracts: a histologic and edemogenic study. J Appl Oral Sci 2012; 20:414-8.

17. Budzynska A, Wieckowska-Szakiel M, Sadowska B, Kalemba D, Rózalska B. Antibiofilm activity of selected plant essential oils and their major components. Pol J Microbiol 2011;60:35-41.
18. Fédération Dentaire International, Commission of Dental Materials, Instruments, Equipment and Therapeutics. Recommended standard practices for biological evaluation of dental materials. Int Dent J 1980;30:140-188.

19. Dezan-Jr E, Sangalli J, Gomes-Filho JE, Gaetti-Jardim Jr E. Psidium cattleianum plus $\mathrm{Ca}(\mathrm{OH}) 2$ antimicrobial efficacy against Enterococcus faecalis. IADR; 15-16,2010, J Dent Res; 2010;89, Special Issue B.

20. Barnard D, Davies J, Figdor D. Susceptibility of Actinomyces israelii to antibiotics, sodium hypochlorite and calcium hydroxide. Int Endod J 1996;29:320-326.

21. Ferreira FB, Torres $S A$, Rosa OP, Ferreira CM, Garcia RB, Marcucci MC, et al.. Antimicrobial effect of propolis and other substances against selected endodontic pathogens. Oral Surg Oral Med Oral Pathol Oral Radiol Endod 2007;104:709-716.

22. Abbaszadegan A, Dadolahi $S$, Gholami A, Moein MR, Hamedani $S$, Ghasemi Y, et al.. Antimicrobial and cytotoxic activity of Cinnamomum zeylanicum, calcium hydroxide, and triple antibiotic paste as root canal dressing materials. J Contemp Dent Pract 2016;1;17:105-113.

23. Passari LM, Scarminio IS, Bruns RE. Experimental designs characterizing seasonal variations and solvent effects on the quantities of coumarin and related metabolites from Mikania laevigata. Anal Chim Acta 2014;22;821:89-96.

24. Tortoriello J, Meckes-Fischer M, Villarreal ML, Berlin B, Berlin E. Spasmolytic activity of medicinal plants used to treat gastrointestinal and respiratory diseases in the Highland of Chiapas. Phytomedicine 1995;2:57-66.

25. Martini ND, Katerere DR, Eloff JN. Biological activity of five antibacterial flavonoids from Combretum erythrophyllum (Combretaceae). J Ethnopharmacol 2004;93:207-12.

26. Cowan MM: Plant products as antimicrobial agents. Clin Microbiol Rev 1999;12:564-582.

27. Sutton SV, Proud DW, Rachui S, Brannan DK. Validation of microbial recovery from disinfectants. PDA J Pharm Sci Technol 2002;5:255-266.

Received November 13, 2016 Accepted March 4, 2017 